\title{
Hubungan Rugositas Terumbu Karang terhadap Struktur Komunitas Ikan Corallivor dan Herbivor di Perairan Pemuteran, Bali
}

\author{
Nidzar Muhammad Raflya ${ }^{\mathrm{a}}$ I Wayan Gede Astawa Karang ${ }^{\mathrm{a}}$, Widiastuti ${ }^{\mathrm{a}^{*}}$ \\ ${ }^{a}$ Program Studi Ilmu Kelautan, Fakultas Kelautan dan Perikanan, Universitas Udayana, Bali, Indonesia \\ Corresponding author email : widiastutikarim@unud.ac.id
}

\section{ARTICLE INFO}

Article history:

Received: January $9^{\text {th }} 2019$

Received in revised form: February $12^{\text {th }} 2019$

Accepted: June $14^{\text {th }} 2019$

Available online: February $28^{\text {th }} 2020$

Keywords:

Rugosity

Corallivorus

Herbivorus

Pemuteran
ABSTRACT

Reef fishes are the highest number of organisms that can be found in coral reefs in which the abundance depends on the healthy of this ecosystem. Reef fishes are mainly consisted of corallivorous and herbivorous fish. Corralivorous fish feeds on coral polyps while herbivorous fish feeds on algae. Therefore these fishes are an important indicators in the resilience of coral reefs. Studies showed that its abundance is strongly correlated with reef's conture (rugosity). Pemuteran waters is one of developing tourists attraction in the north Bali island. However, the data of reef fishes and coral reefs in Pemuteran waters remain limited. Therefore, this research aimed to study the reef condition and rugosity in Pemuteran waters, also to examine the correlation between reefs fishes and reefs rugosity in this area. There were four stations according to purposive sampling method. Data of corallivorous and herbivorous fishes were collected by using the underwater visual census with a $40 \mathrm{~m} 2$ transect. Reef rugosity index were determined by using chain transect method. Results showed that reef rugosity in Pemuteran waters was in the medium to high category. Reef rugosity has strong correlation with the total abundance and diversity of corallivorous fishes. However, reef rugosity was only strong correlated with the total abundance but not with the diversity of herbivorous fishes.

2020 JMRT. All rights reserved.

\section{Pendahuluan}

Terumbu karang merupakan ekosistem yang utamanya dibangun oleh hewan karang (Giyanto et al., 2017). Terumbu karang berfungsi sebagai pelindung pantai dari gelombang ombak maupun arus, selain itu terumbu karang juga mempunyai fungsi ekologis yaitu sebagai habitat hidup, tempat untuk mencari makanan, tempat berkembang, dan juga sebagai tempat pemijahan biota laut (Guntur et al., 2016). Ekosistem terumbu karang memiliki beberapa biota asosiasi yaitu ikan, puluhan spesies moluska, krustasea, sponges, alga, serta biota laut lainnya (Dahuri, 2000). Ekosistem terumbu karang memiliki biota asosiasi yang sangat banyak, salah satunya adalah ikan. Ikan merupakan salah satu biota asosiasi paling banyak yang ditemukan di ekosistem terumbu karang dimana, kehidupan ikan karang sangat bergantung pada kondisi kesehatan terumbu karang (Rondonuwu et al., 2013).

Giyanto et al. (2014) mengelompokkan ikan karang berdasarkan fungsi ekologinya yaitu ikan corallivor dan herbivor. Ikan corallivor merupakan ikan pemakan polip karang yang sebagian besar terdiri dari famili Chaetodontidae (Titaheluw et al., 2015), sehingga keberadaan kelompok ikan ini di ekosistem terumbu karang dapat menjadi indikator terhadap kesehatan ekosistem terumbu karang. Hal ini berarti apabila populasi kelompok jenis ini menurun, maka dapat menunjukkan adanya tekanan terhadap kondisi dan kesehatan terumbu karang (Supriharyono dan Indrawan, 2011). Kelompok ikan herbivor yaitu ikan pemakan makroalga yang merupakan komponen utama untuk mengontrol keseimbangan ekosistem terumbu karang.

Komunitas terumbu karang yang memiliki luasan tertentu dapat membentuk struktur terumbu karang yang kompleks (Waskita, 2016). Struktur habitat penyusun ekosistem terumbu karang yang kompleks dapat menghasilkan beragamnya bentuk relung atau celah antara terumbu karang (Farsia dan Wardah, 2014). Menurut Magno and Villanoy (2006), kondisi ketidak seragaman bentuk relif atau ketidakteraturan topografi terumbu karang dapat dinyatakan sebagai rugositas.

Kawasan Perairan Pemuteran merupakan salah satu kawasan wisata perairan yang terkenal di Bali. Kawasan Perairan Pemuteran juga menjadi salah satu tempat pengembangan transplantasi terumbu karang dengan menggunakan metode biorock yang terbesar di Bali. Pengembangan transplantasi yang begitu besar juga harus diimbangi dengan pengembangan dan pembaharuan terkini terkait keadaan dan kondisi terumbu karang alami begitupun dengan biota-biota yang berasosiasi didalamnya salah satunya yaitu ikan karang. Selain ikan karang, kondisi kompleksitas terumbu karang juga harus menjadi perhatian penting terhadap kelangsungan hidup ekosistem terumbu karang, salah satunya yaitu rugositas terumbu karang. Penelitian yang dilakukan Rodriguez (2006) di Mona Island menunjukkan bahwa rugositas karang merupakan faktor yang dapat memprediksi kelimpahan dan kepadatan ikan karang. Perbedaan jenis morfologi karang penyusun kompleksitas habitat memiliki pengaruh yang berbeda terhadap penggunaan habitat oleh ikan karang dan kompleksitas topografi terumbu karang (Palacios and Zapata, 2013). Suroso (2012) juga menyatakan bahwa terumbu 
karang yang berada di letak geografis yang tidak sama memiliki jenis terumbu karang yang beragam, sehingga menyebabkan kondisi kontur dasar perairan yang tidak sama pada lokasi yang lainnya. Penelitian ini memiliki tujuan untuk mengetahui rugositas terumbu karang, struktur komunitas ikan corallivor dan herbivor di Perairan Pemuteran serta hubungan antara rugositas terumbu karang dengan struktur komunitas ikan corallivor dan herbivor di Perairan Pemuteran.

\section{Metode}

\subsection{Waktu dan Tempat}

Pengambilan data ikan corallivor dan herbivor serta rugositas terumbu karang dilakukan pada tanggal 21 - 26 Maret 2018. Lokasi pengambilan data dilakukan di Perairan Pemuteran, Kecamatan Gerokgak, Kabupaten Buleleng, Bali (Gambar 1).
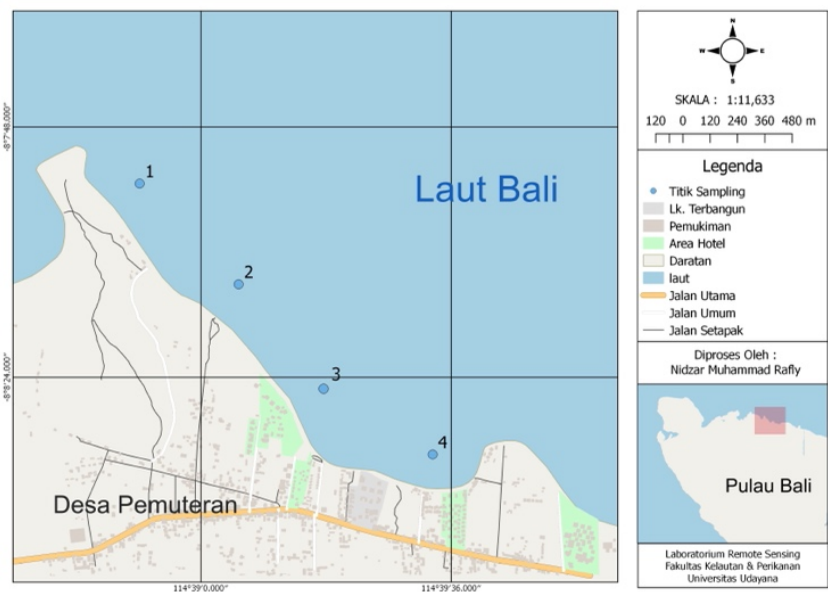

Gambar 1. Peta Lokasi Penelitian

\subsection{Alat dan Bahan}

Alat dan bahan yang digunakan dalam penelitian ini ditunjukkan pada Tabel 1 .

Tabel 1. Alat dan bahan serta kegunaannya dalam penelitian.

\begin{tabular}{|c|c|c|c|}
\hline No & Alat & & Kegunaan \\
\hline 1 & Scuba Set & 1 set & Alat bantu menyelam \\
\hline 2 & Roll meter & 1 buah & $\begin{array}{l}\text { Alat untuk menentukan jarak } \\
\text { transek }\end{array}$ \\
\hline 3 & Transek rantai & 1 buah & $\begin{array}{l}\text { Alat untuk mengukur nilai } \\
\text { rugositas terumbu karang }\end{array}$ \\
\hline 4 & GPS & 1 buah & $\begin{array}{l}\text { Alat untuk menentukan posisi } \\
\text { sampling }\end{array}$ \\
\hline 5 & $\begin{array}{l}\text { Kamera bawah air } \\
\text { (Nikon coolpix } \\
\text { W100) }\end{array}$ & 1 buah & $\begin{array}{l}\text { Alat untuk dokumentasi bawah } \\
\text { air }\end{array}$ \\
\hline 6 & Water quality meter & 1 set & $\begin{array}{l}\text { Alat untuk mengukur kualitas } \\
\text { perairan. }\end{array}$ \\
\hline 7 & $\begin{array}{l}\text { Buku panduan } \\
\text { identifikasi ikan } \\
\text { karang (Allen and } \\
\text { Erdmann, 2009; } \\
\text { Setiawan, 2010; } \\
\text { Giyanto et al., } \\
\text { 2014). }\end{array}$ & & $\begin{array}{l}\text { Panduan identifikasi } \\
\text { karang. }\end{array}$ \\
\hline
\end{tabular}

\subsection{Metode Penelitian}

\subsubsection{Penentuan Stasiun Penelitian}

Penentuan stasiun penelitian ditentukan dengan menggunakan metode purposive sampling dimana terdapat 4 stasiun penelitian dengan masing-masing 3 ulangan transek. Posisi transek mengikuti garis pantai pada kedalaman 5-6 meter dan jarak antar stasiun $\pm 500 \mathrm{~m}$. Luasan terumbu karang tidak sama di setiap stasiun sehingga ukuran luas stasiun mengikuti ukuran luas terumbu karang.

\subsubsection{Pengambilan Data Ikan Karang}

Pengambilan data ikan corallivor dan herbivor dilakukan menggunakan metode sensus visual bawah air (underwater visual census) (English et al., 1997). Transek dibentangkan sepanjang $20 \mathrm{~m}$ dengan batas kanan kiri sepanjang $1 \mathrm{~m}$ (Gambar 2). Ikan corallivor dan herbivor diidetifikasi menggunakan buku panduan identifikasi ikan karang (Allen and Erdmann, 2009; Setiawan, 2010; Giyanto et al., 2014).

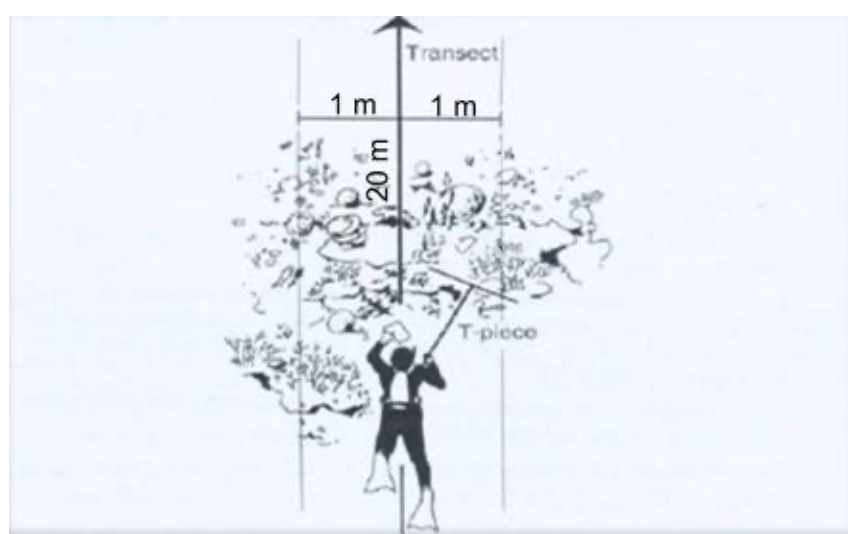

Gambar 2. Skema pengambilan data menggunakan sensus visual ikan karang (English et al., 1997)

\subsubsection{Pengambilan Data Rugositas Terumbu Karang}

Nilai rugositas terumbu karang dilakukan pengamatan menggunakan metode transek rantai (chain intercept transect) (Hill and Wilkinson, 2004). Pengambilan data rugositas terumbu karang dilakukan dengan meletakkan rantai besi dengan diameter ukuran $66 \mathrm{~mm}$ sepanjang $20 \mathrm{~m}$ mengikuti kontur terumbu karang (Hill and Wilkinson, 2004). Skema transek ditunjukkan pada Gambar 3

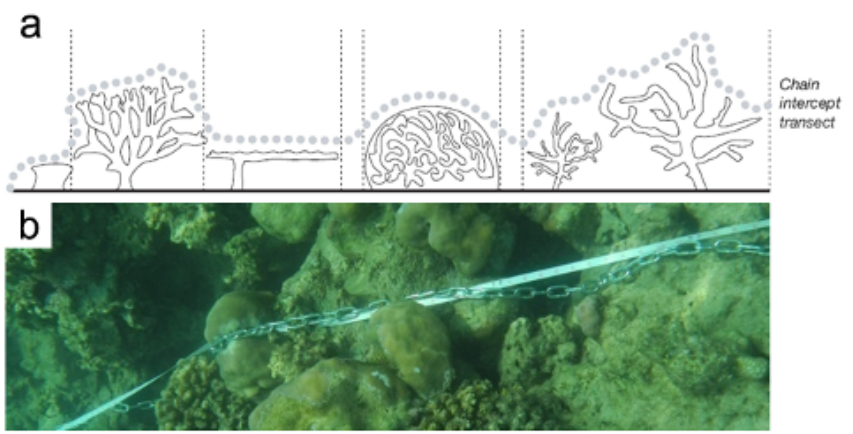

Gambar 3. a) Skema transek rantai (Hill and Wilkison, 2004), b) pengukuran lapangan 


\subsubsection{Analisis Data}

\section{a. Struktur Komunitas Ikan Corallivor dan Herbivor}

Parameter yang diamati pada data struktur komunitas ikan corallivor dan herbivor antara lain; kelimpahan total $(\mathrm{N})$ dan kelimpahan jenis serta indeks keanekaragaman (H'). Kelimpahan menurut Brower and Zar (1997) yaitu jumlah individu persatuan luas yang ditunjukkan pada persamaan 1, dimana adalah jumlah total individu pada tiap stasiun dan A adalah luas daerah pengamatan $(\mathrm{m})$.

$\mathrm{N}=\frac{\sum \mathrm{n}}{A}$

Untuk mengetahui besarnya keanekaragaman jenis dalam sampling dilakukan analisis Indeks keanekaragaman (Odum, 1998) yang ditunjukan pada persamaan 2.

$$
\begin{aligned}
& H^{\prime}=-\sum p i \text { Ln } p i \\
& p i=\frac{n i}{\Sigma n}
\end{aligned}
$$

Dimana H' adalah keanekaragaman jenis ikan, merupakan kelimpahan dari spesies ke-i, ni merupakan jumlah individu ke-i dan merupakan jumlah total individu. Penentuan indeks keanekaragaman ditentukan apabila $\mathrm{H}^{\prime}<1$ dikategorikan sebagai keanekaragaman rendah; bila $\mathrm{H}^{\prime} \geq 1$ dan $<3$ dikategorikan sebagai keanekaragaman sedang; dan bila $\mathrm{H}^{\prime} \geq 3$ dikategorikan sebagai keanekaragaman tinggi.

\section{b. Nilai Rugositas Terumbu Karang}

Nilai rugositas terumbu karang dianalisis berdasarkan panjang transek rantai yang dibentangkan mengikuti kontur terumbu karang sepanjang 20 meter dan dianalisa menggunakan persamaan 3 (Hill and Wilkinson, 2004; Fuad, 2010).

Rugositas $=1-d / l$

Dimana : $d=$ panjang transek yang dibentangkan dalam satu garis lurus dan $l=$ panjang transek rantai yang mengikuti kontur dasar perairan. Hasil dari analisis rugositas terumbu karang kemudian dikelompokan dalam kategori rugositas apabila hasil $<0.170$ merupakan kategori rendah, hasil berkisar antara 0.171-0.275 merupakan kategori sedang dan kategori tinggi apabila hasil $>0.275$.

\subsubsection{Analisis Statistik}

\section{a. Hubungan Rugositas Terumbu Karang dengan Struktur Komunitas}

Hubungan antara rugositas terumbu karang terhadap struktur komunitas ikan corallivor dan herbivor dianalisis dengan korelasi pearson product moment (Sugiyono, 2007) (Persamaan 4), dimana $r$ merupakan koefisien korelasi pearson, $\mathrm{X}$ adalah nilai rugositas terumbu karang, Y merupakan indikator struktur komunitas ikan dan $n$ merupakan banyaknya data.

$r=\frac{\mathrm{n} \sum \mathrm{XY}-\sum \mathrm{X} \sum \mathrm{Y}}{\sqrt{\left[\mathrm{n} \sum \mathrm{X}^{2}-\left(\sum \mathrm{X}\right)^{2}\right]\left[\mathrm{n} \sum \mathrm{Y}^{2}-\left(\sum \mathrm{Y}\right)^{2}\right.}}$

Hasil dari analisis pearson product moment diintrepretasi menjadi hubungan masing-masing variabel yang ditampilkan pada tabel 2 .
Tabel 2. Angka intrepretasi korelasi pearson product moment

\begin{tabular}{ll}
\hline Angka Interpretasi & Hubungan Korelasi \\
$0-0,199$ & Sangat lemah \\
$0,20-0,399$ & Lemah \\
$0,40-0,599$ & Sedang \\
$0,60-0,799$ & Kuat \\
$0,80-1,0$ & Sangat Kuat \\
\hline
\end{tabular}

\section{b. Perbedaan Kelimpahan Ikan Corallivor dan Herbivor}

Uji independent T-test dilakukan untuk menganalisis perbedaan rata-rata kelimpahan total ikan corallivor dengan ikan herbivor dalam setiap stasiun dengan syarat data harus berdistribusi normal $(\mathrm{p}>0.05)$.

\section{Hasil dan Pembahasan}

\subsection{Rugositas Terumbu Karang}

Hasil pengukuran nilai rugositas terumbu karang pada masing-masing stasiun berkisar antara 0.203-0.398 dengan nilai rugositas terumbu karang terendah pada stasiun 2 sedangkan nilai rugositas terumbu karang tertinggi pada stasiun 1 (Gambar 4). Tingginya nilai rugositas terumbu karang disebabkan oleh tingginya tutupan karang jenis massive yang berukuran besar. Rendahnya rugositas pada stasiun 2 dikarenakan kondisi kontur dasar terumbu karang didominasi oleh karang jenis massive yang berukuran kecil dengan jarak yang berjauhan sehingga tidak menimbulkan lekukan kontur dasar yang tinggi.

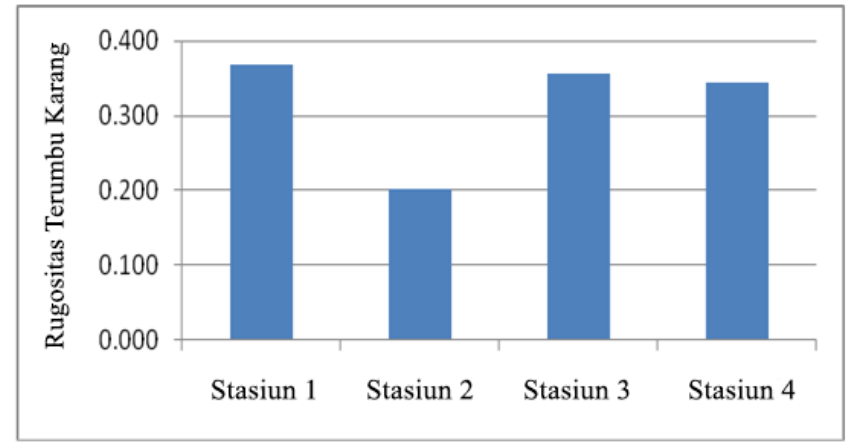

Gambar 4. Grafik nilai rugositas terumbu karang

Berdasarkan kriteria nilai rugositas, stasiun 2 termasuk kriteria rugositas sedang dengan nilai 0.203 sedangkan stasiun 1,3 dan 4 termasuk kedalam kriteria rugositas tinggi. Rugositas dengan kriteria tinggi menandakan bahwa terdapat banyak celah diantara terumbu karang, hal tersebut sesuai dengan pernyataan Muniaha et al. (2016) dimana semakin tinggi nilai rugositas terumbu karang menggambarkan beragamnya bentuk pertumbuhan karang yang memperbanyak celah dan lubang pada terumbu karang. Persentase tutupan karang hidup di setiap stasiun di Perairan Pemuteran yang didominasi oleh bentuk pertumbuhan coral massive dengan ukuran yang beragam (Gambar 5). 


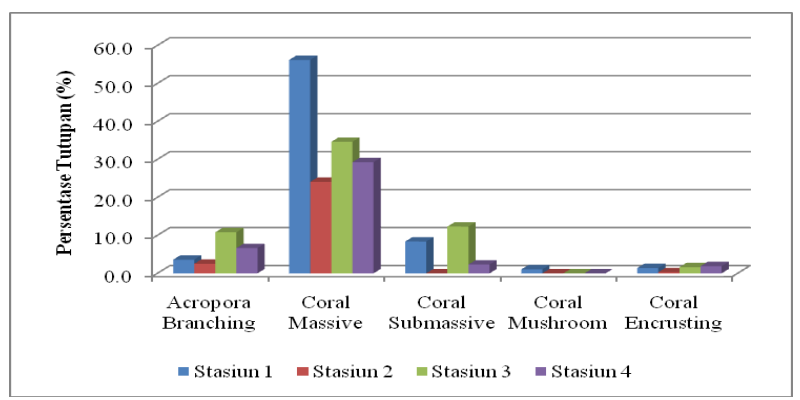

Gambar 5. Bentuk pertumbuhan karang hidup

\subsection{Struktur Komunitas Ikan Corallivor dan Herbivor}

\subsubsection{Kelimpahan Jenis dan Kelimpahan Total}

Berdasarkan hasil pengamatan, jumlah total spesies di Perairan Pemuteran terdapat 4 spesies ikan corallivor yaitu Chaetodon baronessa, C. lunulatus, C. rafflesi, dan Heniochus varius yang semuanya termasuk kedalam famili Chaetodontidae (Gambar 6). Rendahnya jumlah spesies yang termasuk kedalam ikan corallivor di Perairan Pemuteran dikarenakan tingginya dominasi karang jenis massive dimana ikan corallivor lebih meyukai karang dengan tipe pertumbuhan coral branching, khususnya genus Acroporidae (Maddupa, 2006).

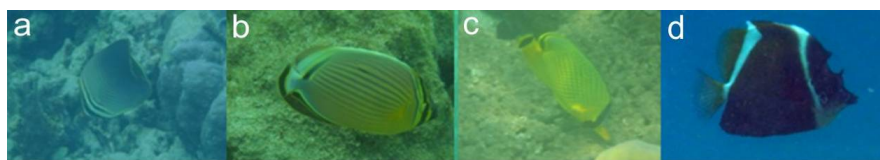

Gambar 6. Ikan corallivor di Perairan Pemuteran; (a) Chaetodon baronessa, (b) C. lunulatus, (c) C. rafflesi, (d) Heniochus varius

Jumlah total spesies ikan herbivor yaitu sebanyak 8 spesies antara lain, Ctenochaetus striatus, Zebrasoma scopas, Plectroglyphidodon lacrymatus, Pomacentrus cuneatus, $P$. moluccensis, Amblyglyphidodon curacao, Dischistodus melanotus dan Hemiglyphidodon plagiometopon yang dikelompokkan ke dalam famili Acanthuridae dan Pomacentridae (Gambar 7).

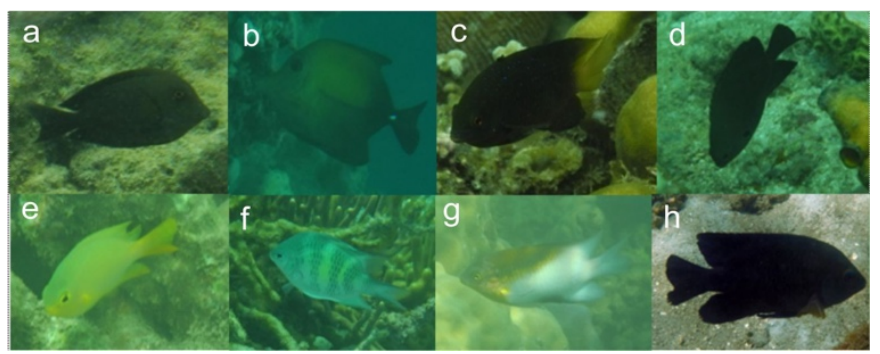

Gambar 7. Ikan herbivor di Perairan Pemuteran; (a) Ctenochaetus striatus, (b) Zebrasoma scopas, (c) Plectroglyphidodon lacrymatus, (d) Pomacentrus cuneatus, (e) Pomacentrus moluccensis, (f) Amblyglyphidodon curacao, (g) Dischistodus melanotus, (h) Hemiglyphidodon plagiometop.

Ikan dari famili Pomacentridae mudah beradaptasi dengan lingkungan yang ditempatinya. Menurut Zulfianti (2014), ikan Pomacentridae dapat hidup pada lingkungan dengan kondisi yang beragam, menempati setiap tempat dengan bentuk yang bervariasi di terumbu karang, bersifat teritorial, hidup berasosiasi dengan karang, substrat berbatu, berpasir dan berlumpur.

Kelimpahan total ikan corallivor dan herbivor di tiap stasiun berdasarkan Uji $\mathrm{T}$ berbeda secara signifikan (Gambar 8). Kelimpahan total ikan jenis herbivor lebih tinggi daripada ikan corallivor di semua stasiun. Kelimpahan total ikan corallivor tertinggi terdapat pada stasiun 1 dengan nilai kelimpahan 0.18 yaitu pada jenis Chaetodon baronessa dan Heniocus varius.

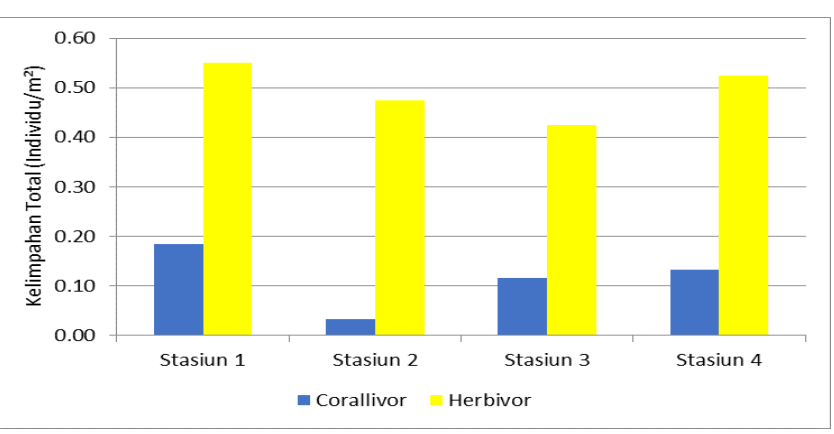

Gambar 8. Kelimpahan total ikan corallivor dan herbivor pada setiap stasiun.

Tingginya kelimpahan total tersebut dikarenakan tutupan karang hidup pada stasiun 1 yang tinggi pula (Tabel 3), hal ini sejalan dengan pendapat Riansyah et al. (2018) bahwa semakin besar persentase tutupan karang hidup maka akan meningkat pula jumlah ikan corallivor yang termasuk famili Chaetodontidae. Stasiun dengan kelimpahan total terendah terdapat pada stasiun 2 dengan hanya jenis Chaetodon baronessa yang ditemukan. Rendahnya jumlah jenis tersebut dikarenakan rendahnya nilai tutupan karang hidup yang terdapat pada stasiun 2 (Tabel 3). Titaheluw (2011) mengatakan bahwa tinggi rendahnya kelimpahan ikan corallivor dalam famili Chaetodontidae memiliki kaitan dengan kondisi tutupan terumbu karang dalam kategori baik.

Tabel 3. Persentase tutupan karang

\begin{tabular}{lcccc}
\hline & Stasiun 1 & \multicolumn{3}{c}{$\begin{array}{c}\text { Stasiun 2 } \\
\text { Persentase (\%) }\end{array}$} \\
\hline Karang hidup & 70.2 & 26.9 & 59.4 & Stasiun 4 \\
Karang mati & 9.0 & 31.4 & 16.1 & 29.1 \\
Alga & 3.5 & 3.5 & 4.9 & 9.5 \\
Abiotik & 14.1 & 38.3 & 29.2 & 28.1 \\
\hline
\end{tabular}

Kelimpahan total ikan herbivor tertinggi terdapat pada stasiun 1 sebesar 0.55 dan terendah terdapat pada stasiun 3 dengan nilai 0.43 (Gambar 3). Ikan jenis Plectroglyphidodon lacrymatus merupakan ikan dengan kelimpahan yang paling tinggi sedangkan ikan jenis Ctenochaetus striatus merupakan ikan dengan kelimpahan terendah. Kelimpahan total ikan herbivor didominasi oleh famili Pomacentridae yang melimpah dan terdapat di semua stasiun hal tersebut dikarenakan famili tersebut bersifat teritorial, relatif stabil, dan dapat dijumpai mulai dari daerah pasang surut hingga mencapai kedalaman $40 \mathrm{~m}$ (Sugianti dan Mujiyanto, 2013).

Indeks keanekaragaman (H') ikan corallivor dan herbivor memiliki nilai yang berbeda-beda pada tiap stasiun (Tabel 4). Keanekaragaman ikan corallivor memiliki nilai tertinggi yaitu pada stasiun 3 dan keanekaragaman terendah pada stasiun 2 . Nilai indeks keanekaragaman ikan corallivor menunjukkan bahwa pada stasiun 1 dan 2 termasuk dalam kategori keanekaragaman rendah yang menandakan bahwa kestabilan komunitas yang ada dalam kondisi tidak normal, kondisi tersebut dikarenakan pada stasiun 1 hanya ditemukan 2 jenis ikan corallivor dan 1 jenis pada stasiun 2 sedangkan keanekaragaman pada stasiun 3 dan 4 termasuk kedalam kategori sedang. Rendahnya jenis ikan pada stasiun 1 dan 2 dikarenakan rendahnya tutupan karang jenis branching yang didominasi oleh karang jenis massive, menurut Palacios dan Zapata (2013), ikan 
corallivor lebih tertarik dengan karang jenis branching karena memiliki preferensi yang kuat untuk tempat berlindung dan mencari makan.

Tabel 4. Indeks Keanekaragaman

\begin{tabular}{lrrrr}
\hline \multirow{2}{*}{ Keanekaragaman $\left(\mathrm{H}^{\prime}\right)$} & \multicolumn{4}{c}{ Stasiun } \\
\cline { 2 - 5 } & 1 & 2 & 3 & 4 \\
\hline Corallivor & 0.5 & 0.0 & 1.3 & 1.0 \\
Herbivor & 1.4 & 0.9 & 1.2 & 1.1 \\
\hline
\end{tabular}

Keanekaragaman ikan herbivor tertinggi terdapat pada stasiun 1 sebesar 1.4 yang termasuk kedalam kategori sedang. Stasiun 2 menunjukkan keanekaragaman yang rendah. Keanekaragaman pada stasiun 1,3 dan 4 termasuk kedalam kategori sedang $\left(\mathrm{H}^{\prime} \geq 1\right.$ dan $<3$ ), dimana pada setiap stasiun diindikasikan terdapat jenis ikan yang beragam. Menurut Zulfianti (2014), tinggi rendahnya nilai indeks keanekaragaman jenis suatu komunitas ditentukan oleh tinggi rendahnya kelimpahan individu, salah satu penyebab tingginya keanekaragaman spesies ikan pada ekosistem terumbu karang yaitu adanya bentuk pertumbuhan karang yang beragam.

\subsection{Hubungan Rugositas Terumbu Karang Terhadap Struktur Komunitas Ikan Corallivor.}

Korelasi antara rugositas terumbu karang terhadap kelimpahan total ikan corallivor pada setiap stasiun menunjukkan nilai korelasi yang bersifat positif dengan nilai kekuatan hubungan termasuk kedalam kategori kuat (Tabel 5). Hal ini menandakan bahwa terdapat keterkaitan antara keduanya, apabila nilai rugositas terumbu karang meningkat maka nilai kelimpahan total ikan corallivor juga akan meningkat. Hal ini sesuai dengan pernyataan Rodriguez (2006) yaitu kelimpahan ikan karang berkorelasi positif dengan rugositas terumbu karang dan dapat menjadi prediktor yang berguna dari variabel struktur komunitas ikan.

Tabel 5. Analisis korelasi pearson product moment antara rugositas terumbu karang dan struktur komunitas ikan corallivor. Tingkat signifikan $(\mathrm{p}<0.05)$

\begin{tabular}{ll}
\hline Struktur Komunitas & \\
Ikan Corallivor & Rugositas Terumbu Karang \\
\hline Kelimpahan Total & 0.645 \\
Keanekaragaman & 0.632 \\
\hline
\end{tabular}

Korelasi rugositas terumbu karang terhadap keanekaragaman ikan corallivor memiliki nilai korelasi yang bersifat positif dengan nilai hubungan korelasi kuat. Korelasi yang kuat menandakan bahwa rugositas terumbu karang berpengaruh terhadap keanekaragaman ikan corallivor. Berdasarkan pengamatan, tingginya nilai rugositas terumbu karang dikarenakan beragamnya bentuk koloni tutupan terumbu karang yang membentuk topografi yang kompleks selain itu, terumbu dengan tutupan hidup yang tinggi akan berdampak terhadap melimpahnya polip karang sebagai sumber makanan ikan corallivor. Hal ini sesuai dengan Titaheluw et al. (2015) yaitu meningkatnya jumlah tutupan karang hidup akan berdampak semakin banyaknya polip karang sehingga persediaan makanan ikan corallivor akan berlimpah dan berkurang apabila tutupan karang hidup menurun.

\subsection{Hubungan Rugositas Terumbu Karang Terhadap Struktur Komunitas Ikan Herbivor.}

Nilai korelasi antara rugositas terumbu karang terhadap kelimpahan total ikan herbivor menujukan nilai korelasi yang bersifat positif dengan kekuatan hubungan korelasi yang kuat (Tabel 6). Nilai korelasi positif dengan kekuatan hubungan korelasi yang sangat kuat menandakan bahwa terdapat hubungan saling berkaitan antara rugositas terumbu karang dan kelimpahan total ikan herbivor, apabila nilai rugositas terumbu karang meningkat maka nilai kelimpahan total ikan herbivor juga akan meningkat. Nilai korelasi rugositas terumbu karang terhadap keanekaragaman ikan herbivor memiliki korelasi negatif. Korelasi yang negatif menandakan bahwa ketika nilai rugositas turun maka nilai keanekaragaman ikan herbivor akan ikut turun, dengan kekuatan hubungan yang sedang.

Tabel 6. Analisis korelasi pearson product moment terumbu karang dan struktur komunitas ikan herbivor. Tingkat signifikan $(\mathrm{p}<0.05)$.

\begin{tabular}{lr}
$\begin{array}{l}\text { Struktur Komunitas } \\
\text { Ikan Herbivor }\end{array}$ & Rugositas Terumbu Karang \\
\hline Kelimpahan Total & 0.793 \\
Keanekaragaman & $(-0.487)$ \\
\hline
\end{tabular}

\section{Kesimpulan}

Nilai rugositas terumbu karang di Perairan Pemuteran didominasi oleh rugositas kategori tinggi yang disebabkan oleh tingginya tutupan karang massive berukuran besar.

Kelimpahan total ikan corallivor lebih rendah dari ikan herbivor di Perairan Pemuteran, hal ini dikarenakan ikan herbivor lebih mudah untuk beradaptasi dengan lingkungannya. Keanekaragaman ikan corallivor dan herbivor di Perairan Pemuteran dipengaruhi oleh bentuk pertumbuhan karang, sehingga kenekaragaman ikan tinggi terdapat pada lokasi dengan bentuk pertumbuhan karang yang beragam.

Hubungan rugositas terumbu karang terhadap kelimpahan total ikan corallivor bersifat positif dengan kekuatan sangat kuat dan hubungan rugositas terumbu karang terhadap keanekaragaman ikan corallivor bersifat positif dengan kekuatan hubungan lemah (stasiun 2) hingga sangat kuat (stasiun 1).

Hubungan rugositas terumbu karang terhadap kelimpahan total ikan herbivor bersifat positif dengan kekuatan hubungan sangat kuat sedangkan hubungan rugositas terumbu karang terhadap keanekaragaman ikan herbivor bersifat negatif dengan kekuatan lemah hingga tinggi dan bersifat positif hanya di stasiun 4 dengan kekuatan hubungan lemah.

\section{Daftar Pustaka}

Allen GR, Erdmann MV. 2009. A new species of damfish (Pomacentrus; Pomacentridae) from western New Guinea. Record of the Western Australian Museum 25: 121-126.

Brower JE, Zar JH. 1997. Field and Laboratory Method for General Ecology Wm. America:C. Brown Company Publisher.p 301.Behera, S.K., Yamagata,T.,2003. Notes and correspondence, Influence of the Indian Ocean Dipole on the Southern Oscillation. Journal of the Meteorological Society of Japan.81.169-177

Dahuri R. 2000. Pendayagunaan sumberdaya kelautan untuk kesejahteraan rakyat. Lembaga Informasi dan Studi Pembangunan Indonesia. LISPI, Jakarta. 146 halaman.

English S, Wilkinson C, Baker U. 1997. Survey manuals for tropical marine resources. Australia Institute of Marine Science. Townsville. Australia.

Farsia L, Wardah. 2014. Hukum pelestarian terumbu karang sebagai penyangga produktivitas perikanan. Kanun Jurnal Ilmu Hukum No.62, Th. XVI.

Fuad M.A.Z. 2010. Coral reef rugosity and coral biodiversity [tesis]. Netherlands : International Institute For Geo-Information Science And Earth Observation Enschede. 
Giyanto, Manuputty A EW, Abrar M, Siringoringo R M, Suharti S R, Wibowo K, Edrus I N, Arbi U C, Hendrik A.W. Cappenberg, Sihaloho H F, Tuti Y, Anita DZ.2014. Panduan Monitoring Kesehatan Terumbu Karang. Jakarta :CRITC COREMAP CTI - LIPI. 63 hlm.ISBN 978-9793378-84-8.

Giyanto, Abrar M, Hadi T A ,Budiyanto A, Hafizt M, Salatalohy A, Iswar M Y. 2017. Status Terumbu Karang Indonesia. Jakarta : Puslit Oseanografi - LIPI.30 hlm.ISBN 978-602-6664-09-9.

Guntur, Arifin A, Luthfi OM. 2016. Komposisi penyusun terumbu karang tepi (fringing reef) di pulau Mandangin Kabupaten Sampang, Madura. Jurnal Saintek Perikanan Vol.11 No. 2.

Henniege SJ, Smith DJ, Wals SJ, McGinley MP, Warner ME, Suggett TG. 2010. Acclimation and adaption of scleractinian coral communities along environmental gradients within an Indonesian reef system. Journal of Experimental Marine Biology and Ecology 391 (1-2), 143-152.

Hill J, Wilkinson C. 2004. Methods for Ecological Monitoring of Coral Reefs. Townsville : Australian Institute of Marine Science.

Lauwoie I. 2010. Keterkaitan kondisi terumbu karang dengan kelimpahan ikan herbivora di pesisir selatan Teluk Kupang, Provinsi Nusa Tenggara Timur [tesis]. Bogor : Sekolah Pascasarjana, Institut Pertanian Bogor.

Maddupa HH. 2006. Kajian ekobiologi ikan kepe-kepe (Chaetodon octofasciatus, BLOCH 1787) dalam mendeteksi kondisi ekosistem terumbu karang di pulau Petondan Timur, Kepulauan Seribu, Jakarta [Tesis]. Bogor : Institut Pertanian Bogor.

Magno M, Villanoy C. 2006. Quantifiying the complexity of philippine coastline for estimating entrainment potential. in : Proceedings 10th International Coral Reef Symposium. 1471-1476pp

Muniaha H, Nur AI, Rahmadani. 2016. Studi kelimpahan ikan karang berdasarkan kondisi terumbu karang di Desa Tanjung Tiram Kabupaten Konawe Selatan. Jurnal Manajemen Sumberdaya Perairan, 2(1):9-19

Odum EP. 1998. Dasar-dasar Ekologi. Penerjemah ; Samingan T. Edisi Ketiga. Yogyakarta, Indonesia: Universitas Gajah Mada.

Palacios MDM, Zapata FA. 2013. Fish community structure on coral habitats with constrasting architecture in the Tropical Eastern Pasific. Rev. Biol. Trop. : Vol 62.(suppl. 1) 343-357

Riansyah A, Hartono D, Kusuma AB. 2018. Ikan kepe-kepe (Chaetodontidae) sebagai bioindikator kerusakan perairan ekosistem terumbu karang pulau tikus. A Scientific Journal Vol 35.

Rodríguez IB. 2006. Relationships between reef fish communities, water and habitat quality on coral reefs [thesis]. Puerto rico : Marine Science University of Puerto Rico

Rondonuwu AB, Rembet NWJ, Moningkey RD, Tombokan JL, Kambey AD, Wantasen AS.2013. Coral fishes the famili chaetodontidae in coral reef waters of Para Island Sub District Tatoareng, Sangihe Kepulauan Regency. Jurnal Ilmiah Platax 1 (4): 210-215

Setiawan F. 2010. Panduan Lapangan Identifikasi Ikan Karang da Inveterbrata Laut.

Sugianti, Y. dan Mujiyanto. 2013. Biodiversitas ikan karang di perairan Taman Nasional Karimunjawa, Jepara. BAWAL, 5(1):23-31.

Sugiyono. 2007. Metode penelitian administrasi. Bandung : Alfabeta.

Supriharyono, Indrawan W. 2011. Kondisi terumbu karang dengan indikator ikan chaetodontidae di pulau sambangan Kepulauan Karimun Jawa, Jepara, Jawa Tengah. Jurnal Buletin Oseanografi Marina Vol.1 $106-119$ ISSN 2088-3507

Suroso W. 2012. Menengok Kembali Terumbu Karang yang Terancam di Segitiga Terumbu Karang. World Resource Institute. ISBN 978-1-56973798-9

Titaheluw S. 2011. Keterkaitan antara terumbu karang dengan ikan Chaetodontidae : implikasi untuk pengelolaan [tesis]. Institut Pertanian Bogor. Bogor.

Titaheluw S, Kamal M, Ernawati Y. 2015. Hubungan antara ikan chaetodontidae dengan bentuk pertumbuhan karang. Jurnal Ilmiah Agribisnis dan Perikanan. Vol. 8 Edisi 1.

Waskita AM. 2016. Kompleksitas dasar perairan terumbu karang dengan benthic terrain dan in situ rugosity di pulau Kelapa dan Harapan, Kepulauan Seribu, Jakarta [skripsi]. Bogor : Departemen Ilmu dan Teknologi Kelautan, Institut Pertanian Bogor. 